IZA DP No. 6505

The Impact of Redistributive Policies on Inequality in OECD Countries

Philipp Doerrenberg

Andreas Peichl

April 2012 


\title{
The Impact of Redistributive Policies on Inequality in OECD Countries
}

\author{
Philipp Doerrenberg \\ CGS, University of Cologne and IZA \\ Andreas Peichl \\ IZA, University of Cologne, ISER and CESifo
}

\author{
Discussion Paper No. 6505 \\ April 2012
}

IZA

P.O. Box 7240

53072 Bonn

Germany

Phone: +49-228-3894-0

Fax: +49-228-3894-180

E-mail: iza@iza.org

Any opinions expressed here are those of the author(s) and not those of IZA. Research published in this series may include views on policy, but the institute itself takes no institutional policy positions.

The Institute for the Study of Labor (IZA) in Bonn is a local and virtual international research center and a place of communication between science, politics and business. IZA is an independent nonprofit organization supported by Deutsche Post Foundation. The center is associated with the University of Bonn and offers a stimulating research environment through its international network, workshops and conferences, data service, project support, research visits and doctoral program. IZA engages in (i) original and internationally competitive research in all fields of labor economics, (ii) development of policy concepts, and (iii) dissemination of research results and concepts to the interested public.

IZA Discussion Papers often represent preliminary work and are circulated to encourage discussion. Citation of such a paper should account for its provisional character. A revised version may be available directly from the author. 
IZA Discussion Paper No. 6505

April 2012

\section{ABSTRACT \\ The Impact of Redistributive Policies on Inequality in OECD Countries}

Recent discussions about rising inequality in industrialized countries have triggered calls for more government intervention and redistribution. Due to obvious behavioral effects caused by redistribution, it is however not clear whether redistributional policies are indeed able to combat inequality. This paper contributes to this relevant research question by using different contextual country-level data sources to study inequality trends in OECD countries since the 1980s. We first investigate the development of inequality over time before analyzing the question of whether governments can effectively reduce inequality. Different identification strategies, using fixed effects and instrumental variables models, provide some evidence that governments are capable of reducing income inequality despite countervailing behavioral adjustments. The effect is stronger for social expenditure policies than for progressive taxation, which seems to trigger more inequality increasing indirect behavioral effects. Our results also suggest that the use of secondary inequality data should be handled with caution.

JEL Classification: D31, D60, H20

Keywords: inequality, redistribution, social expenditure, progressive taxation

Corresponding author:

Andreas Peichl

IZA

P.O. Box 7240

53072 Bonn

Germany

E-mail: peichl@iza.org

\footnotetext{
* Andreas Peichl is grateful for financial support from the Deutsche Forschungsgemeinschaft DFG. We would like to thank Corrado Giulietti, Martin Guzi, Judith Niehues, Sebastian Siegloch and Eric Sommer for helpful comments and suggestions.
} 


\section{Introduction}

Recent discussions about rising inequality in OECD countries have triggered recurring calls for more government intervention and redistribution (see, e.g., OECD 2011). These calls for action implicitly assume that governments are capable of reducing inequality despite potential countervailing behavioral effects. However, looking at the empirical literature, it is still an open question whether this indeed holds true. In our paper, we contribute to this research question by examining inequality trends in OECD countries between 1981 and 2005 using different country-level data sets. We first look at the development of income inequality over time before investigating whether redistributive policy measures effectively reduce inequality. In particular, we look at the effect of three explanatory policy variables of interestgovernment spending, social expenditure, and progressive taxation - on the Gini coefficient of income inequality. We use different identification strategies to approach our research question and to overcome potential problems of endogeneity.

While the effect of redistributing policies on inequality appears obvious and trivial on the first glance, the expected impact is theoretically less straight-forward if behavioral (second-round) adjustments of economic agents are considered and accounted for. Of course, progressive taxation and social expenditures, which benefit the poor relatively more, reduce the difference between pre- and post-government inequality. This direct inequality reducing effect is confirmed by empirical studies based on individual-level data that study the effect of social policies on the difference between pre- and post-government inequality distributions (e.g., Garfinkel et al. 2006; Fuest et al. 2010). However, one has to also consider indirect second-round effects on the pre-government distribution of income which might yield an opposite effect and could eventually overcompensate the initial positive effect (e.g., Sinn 1995; Poterba 2007). Many redistributive policies such as progressive taxes or social benefits reduce incentives to work or to invest. Given the findings in the literature (e.g., Roed and Strom 2002) that labor supply elasticities are higher at the bottom of the income distribution than at the top, it is likely the case that labor supply reduction in response to redistribution measures is more prevalent among the poor than among the rich. It can thus be presumed that redistribution increases pregovernment inequality and therefore, obviously, also post-government inequality. ${ }^{1}$ Another reason for behavioral second-round effects is grounded in the wage-setting behavior of employers. In countries with high levels of redistribution, employers might shift away any social responsibility because they expect the government to ensure decent levels of inequality and fairness. Following this argument, gross-wages

\footnotetext{
${ }^{1}$ See Niehues (2010) for a more thorough discussion of this argument.
} 
of employees are lower than in a world without redistribution, whereas employers' profits are c.p. higher; thus implying higher pre-government inequality. Both effects potentially (partly) offset the initial positive first-round effect of redistribution on equality. It is to empirical analyses to explore whether second-round effects outweigh first-round effects or not.

Unfortunately, however, finding the causal effect of redistributive generosity on levels of post-government income inequality is characterized by difficulties. As in most empirical applications that strive at finding the effect of policy measures on outcome variables, one has to be aware that policy measures are themselves responsive to economic and/or political conditions and therefore usually endogenous. In order to overcome any resulting empirical problems, careful empirical work requires identifying the channels of how the policies of interest are shaped. All channels that affect both the policy variable and the outcome of interest (confounders) then need to be controlled for in the empirical estimations (Besley and Case 2000). To identify confounding variables in our set-up, we start by studying the seminal theoretical work of Meltzer and Richard (1981). They show that higher inequality tends to cause higher levels of redistribution, because the median voter favors the more redistribution, the further away she is from the mean income. Hayes et al. (1991) and Schwabish et al. (2006), among others, confirm empirically that the income distribution indeed impacts social expenditures. The results in the literature thus suggest that there is an effect of redistributive policies on levels of inequality, but, at the same time, inequality also influences governments' policies. This mechanism of reverse causality makes the econometric identification of the effect of redistributive measures on income inequality particularly difficult. Simply regressing inequality on redistribution levels neglects that high redistribution might have occurred in societies with high inequality in the first place. We further discuss this problem and our identification approaches to overcome endogeneity in the empirical Sections 4.2.1 and 4.3.1.

We rely on several datasets on inequality to make the results more robust to measurement problems (see Section 2 for a discussion of data sets and problems). ${ }^{2}$ We exploit within country variation in a relatively long time series of OECD countries $(1981$ - 2005) and apply different identification strategies, using fixed effects and instrumental variable approaches, to tackle problems of endogeneity. In addition, we use a rather new data set to measure the effect of tax progressivity.

Our results partly confirm that redistributive policies based on government expenditure serve their aim to reduce inequality, despite potential offsetting second-

\footnotetext{
${ }^{2} \mathrm{We}$, however, refrain from merging different data sources as inequality data are usually not comparable across data sources.
} 
round effects. As for our precisely estimated coefficients, we find that a $1 \%$ increase in government spending or public social expenditure is roughly related to a $0.3 \%$ drop in inequality. The effects of changes in tax progressivity are less clear and often insignificant implying that indirect behavioral effects play a (bigger) role with tax progressivity. This suggests that governments aiming at reducing inequality should rely more on social expenditure rather than on increasing the progressivity of income taxes. Our results also show that (different) inequality data sources should always be handled with caution.

Despite its policy relevance, the causal effect of redistributive policies on the income distribution has so far found surprisingly little attention in the literature. ${ }^{3}$ Chong and Gradstein (2007) find that the quality of institutions positively affects the distribution of incomes. Checchi and Garcia-Penalosa (2008) and Checchi and Garcia-Penalosa (2010) find empirical evidence for the importance of labor market institutions on reducing inequality when applying a three-stage-least-squares estimator. Calderon and Chong (2009) look at a similar research question and obtain confirmative results. A paper by Niehues (2010) provides evidence that more generous welfare states, in terms of total social benefits relative to GDP, achieve higher economic equality. Duncan and Sabirianova-Peter (2008) find that progressive taxation reduces income inequality based on an IV approach. The study of Roine et al. (2009) establishes a negative relationship between inequality and government spending as a share of GDP as well as top marginal tax rates, while Cooper et al. (2011) exploit variation in US federal and state taxes to find that tax policies, on the federal level in particular, compress the income distribution.

The proceeding of this paper is as follows. We first discuss several data sources for measures of inequality (Section 2). In a next step, Section 3 exploits all data sources discussed to sketch the development of inequality in OECD countries over time. Section 4 contains the multivariate regression analyses. Therein, the included variables and their data sources are presented, before fixed effects and IV models are estimated and discussed. Finally, Section 5 concludes.

\section{Inequality Data}

The use of (readily available) inequality data usually comes with a considerable amount of pitfalls (Atkinson and Brandolini 2001). Conducting a cross-country study over time, we particularly have to attach importance to consistency and

\footnotetext{
${ }^{3}$ This is certainly partly due to the inherent problems of endogeneity and reverse causality. Issues of data quality, as discussed in Section 2, are another reason.
} 
comparability of the data both over time and between countries. Although Gini coefficients - the most common and popular measure of inequality - are available for a wide range of countries, comparability remains a major problem and methods of calculating are often inconsistent across different datasets, and sometimes even within the same dataset. Consequently, as put forward by Atkinson and Brandolini (2001, p. 772), "we cannot therefore be sure whether results of comparative or econometric analyses obtained using such data are genuine or a product of data differences." 4 For example, one major problem in calculating the Gini coefficient is that the unit of analysis sometimes is the entire household, whereas it is the individual elsewhere (Atkinson and Brandolini 2001; Galbraith and Kum 2005). In this paper, we attempt to achieve the best-possible consistency by, firstly, not blending together inequality data from different data sources, which rely on different methods of calculating inequality measures, and secondly, by restricting our analyses to a set of relatively homogeneous OECD countries. We, thirdly, also employ different datasets in order to increase the robustness of the results.

Another pitfall in many datasets is that they either do not cover many countries and points of time or are highly unbalanced. This often hinders the use of advanced econometric panel data techniques. Data restrictions also forbid to look at different types of inequality. We have to rely on inequality in disposable income in all analyses, although it might as well be interesting to look at wage or wealth inequalities.

As for the measurement of income inequality, we mostly rely on the Gini coefficient which is by far the most frequently used measure of inequality in the literature. In order to achieve a sufficient high coverage of countries and points of time, the reliance on the Gini coefficient is inevitable. The data used in our analyses exhibit the largest coverage of OECD countries over time among all data sources consisting of inequality measures. Having the drawbacks and restrictions regarding data and inequality measurements in mind, we describe the datasets used in our analyses in the following. ${ }^{5}$

Luxembourg Income Study (LIS) Data of the LIS (LIS 2012) provide the possibility to derive inequality measures from individual-level data, which are consistent both across time and between countries. All measures are based on national household surveys. The original data are harmonized and standardized on the individual level before the aggregated Gini coefficients are calculated. This ensures a

\footnotetext{
${ }^{4}$ In their survey of inequality data, Atkinson and Brandolini (2001) provide many examples of inconsistencies both across and within datasets.

${ }^{5}$ We utilize the Quality of Government (QoG) Social Policy Dataset provided by Samanni et al. (2010). It combines and merges different country-level data sources, among which are all inequality data sources we employ in our analyses.
} 
high comparability of the data, but makes a wide coverage of countries and years impossible. Although 24 OECD countries are included in the dataset in total, there are only between 8 to 17 countries represented in each wave, also indicating that the panel is highly unbalanced.

UN World Income Inequality Database (WIID) Based at the United Nations University World Institute for Development Economic Research (UNU-WIDER 2008), this dataset is one of the largest and most comprehensive inequality panel data sets. It builds on the dataset by Deininger and Squire $(1996)^{6}$, but goes beyond it by increasing the number of included countries, extending the time frame up to 2006. We employ the latest version of the data, named WIID V2.0C as of May 2008 to obtain Gini coefficients. The coverage of both countries and years is relatively large. The unbalanced panel we rely on consists of 30 OECD countries between 1980 and 2006; on average there are 18.2 countries per year. The data contain a variable indicating the quality and reliability of the respective Gini coefficient and we only rely on the highest level of data quality for our analysis.

University of Texas Inequality Project (UTIP) Based at the University of Texas, this data source (Galbraith and Kum 2005; Galbraith 2009) is intended to overcome pitfalls identified in the Deininger and Squire (1996) data. The basic idea behind the estimates of inequality is that the United Nations Industrial Development Organization (UNIDO) provides consistent measures of inequality of wages in the industrial sector, which are likely to be related to household income inequality. To obtain estimates of inequality, the Deininger and Squire (1996) data are regressed on: (i) inequality in manufacturing pay - obtained from the UNIDO - , (ii) the share of workers in the manufacturing sector to the population, and (iii) three dummies of data sources ${ }^{7}$ used by Deininger and Squire (1996). The resulting estimates then serve as the measures of inequality. Compared to the Deininger and Squire (1996) dataset, they also extend the coverage of both time and countries. All in all, 28 OECD countries are represented between 1963 and 2002. On average, there are 25.8 country observations per year.

\footnotetext{
${ }^{6}$ The initial Deininger and Squire data are among the most widely used data sources in the literature on inequality. The dataset only includes measures of the Gini coefficients that meet three conditions: data are (i) based on household surveys, (ii) cover a sufficient share of the population and (iii) considers a comprehensive coverage of different income sources. However, it is yet criticized for its various inconsistencies, most strikingly in the use of different income concepts (e.g., Atkinson and Brandolini 2001). The original data only run until 1996, which is why we rely on the UNU-WIDER extension.

${ }^{7}$ Income vs. expenditure, gross vs. net of taxes, household vs. personal unit of analysis.
} 


\section{The Development of Inequality over Time}

In this section, we present descriptive overviews of the development of inequality over time. For brevity, besides looking at the OECD average, we classify countries into several types of homogeneous welfare states. As the welfare type groups differ with respect to institutions such as power of unions in wage bargaining, generosity of unemployment benefits, tax systems, etc., systematic differences across welfare type families provide a first hint that institutions matter for levels of inequality. ${ }^{8}$

Figures 1 and 2 below, as well as Figures 3 and 4 in the Appendix, display inequality trends over time. We calculate moving averages of 5 years in order to smooth the time lines. Using all three different data sources, we first examine the development of inequality for the average of all OECD countries in Figure 1. The unit of measurement for the LIS and WIID data is the Gini coefficient, UTIP data represent estimates as described before. Although all three data sources depict somewhat different developments and trends, there appears to be a common pattern: Average inequality in OECD countries has increased since the early and mid 1980s, confirming the discussions held in the public media. Both the WIID and UTIP data suggest a little decrease since 2000, while the LIS data display a large increase. Reasons might be due to either different measurement methods or a lack of recent and reliable data for particular countries.

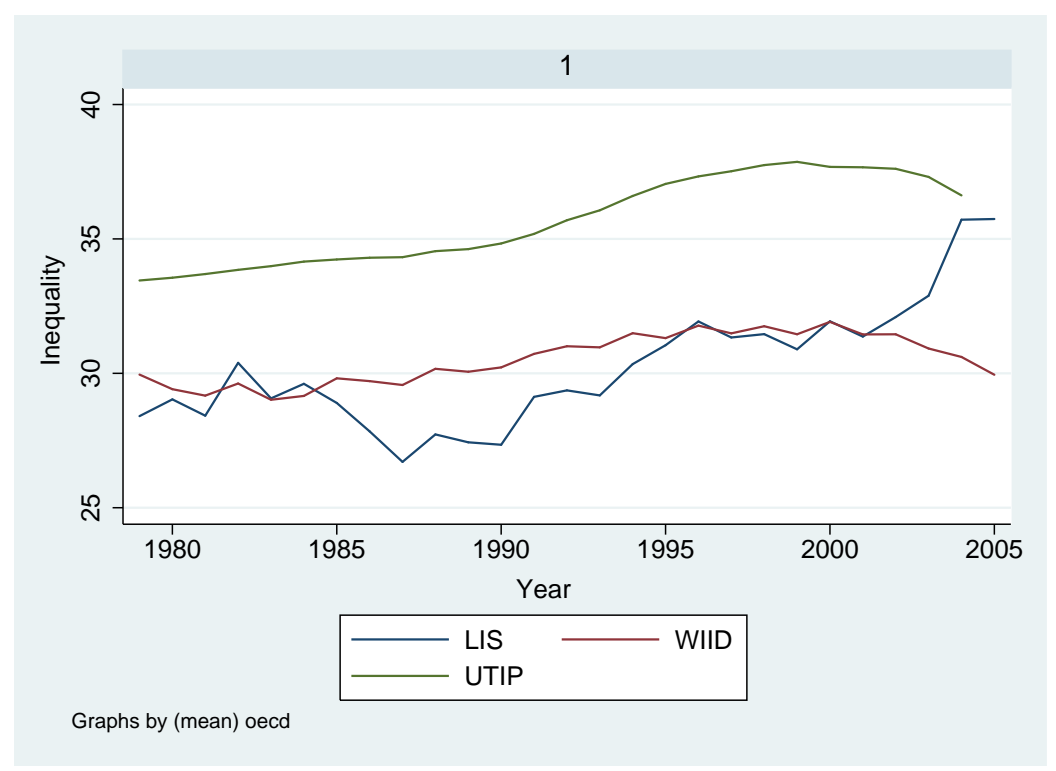

Figure 1: Inequality in OECD over time

\footnotetext{
${ }^{8}$ Following the literature, we sort countries into the following welfare regimes: Liberal (Canada, Japan, USA, Switzerland), Social-democratic (Denmark, Finland, Iceland, Norway, Sweden), Conservative (Austria, Belgium, France, Germany, Luxembourg, Netherlands), Radical (Australia, Ireland, UK), Southern (Greece, Italy, Portugal, Spain), Eastern (Czech Republic, Hungary, South Korea, Poland, Slovakia) and Other (Mexico, New Zealand, Turkey).
} 
Looking at inequality trends separately for different types of welfare regimes in Figure 2 (where the UTIP dataset is used), we confirm the pattern that inequality has increased since the early/mid eighties. The trends show that the rise is the highest in eastern, radical and other welfare types. While it had the lowest levels of inequality before their transition from socialism to democracies, the family of eastern countries has experienced a large increase since 1990; putting their levels of inequality above levels in social-democratic and conservative welfare states, and lately even above southern countries. Inequality is the highest in other welfare types. As expected, the social-democratic welfare regimes have both the lowest inequality levels and increases. The observation that, for example, radical and liberal welfare states are characterized by more inequality than social-democratic or conservative ones provides a hint that institutions seem to matter for the income distribution. The large rise in inequality in Eastern European states since the breakdown of socialism in the late 80 s/early 90 s adds to this presumption. Although Figures 3 and 4 in the Appendix depict slightly different trends, the basic patterns are similar as in the UTIP data. However, the results show that inequality is measured highly inconsistently across different data sources, suggesting that different data should not be blended in analyses.

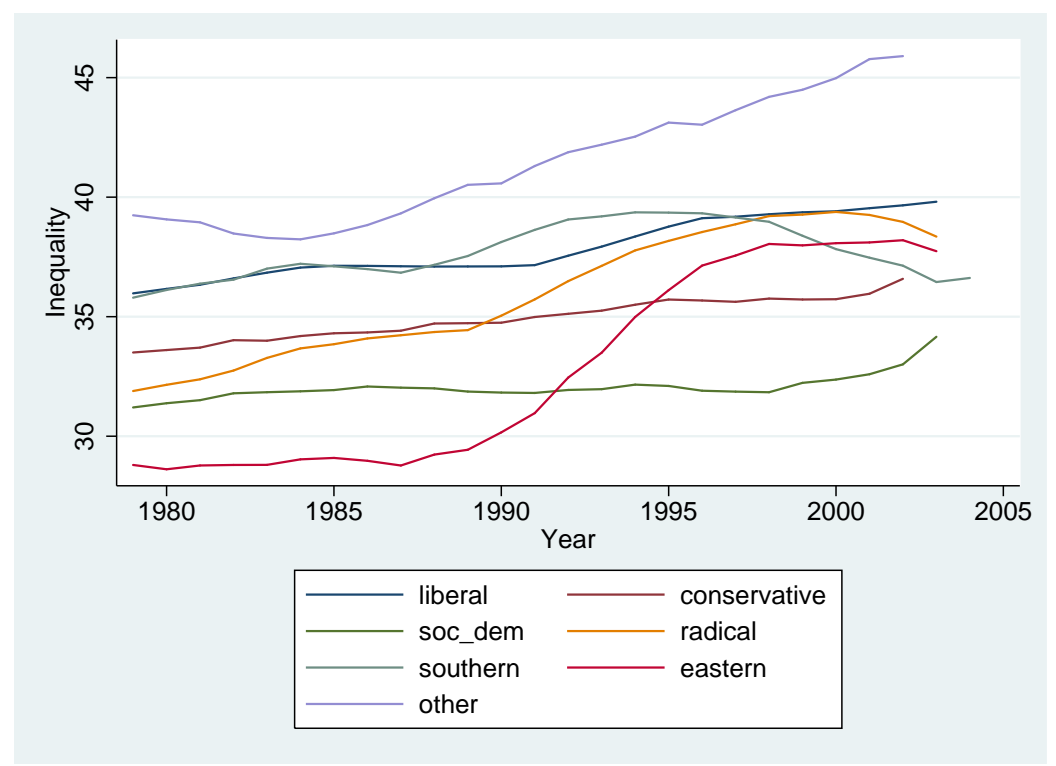

Figure 2: Inequality (utip) by welfare types

\section{The Role of Redistributive Policies}

In order to analyze the effect of redistributive policies on inequality trends, we use different econometric methods which are described below. We start with the 
variables used for the analysis and some summary statistics.

\subsection{Data Sources and Variables}

Dependent Variable: Inequality The measures of inequality are obtained from the data sources discussed and described in Section 2. The sufficient number of observations in these data sets allows to conduct econometric panel analyses. The WIID and LIS data measure inequality with the Gini coefficient, whereas UTIP provides inequality estimates based on a regression estimation (see discussion above).

(Explanatory) Policy Variables of Interest We are interested in the effect of redistributive policy measures on the distribution of incomes. In the analyses we look at three different explanatory variables, which are aimed to capture and measure policies of redistribution: Our first explanatory variable of interest is the level of government spending in a country. The data are obtained from the Penn World Tables (Heston et al. 2009). In the western-industrialized OECD countries in our sample, a large share of government spending is attributed to redistributive expenses such as social benefits, welfare and pensions. Additionally, many services and infrastructural measures undertaken by the government have progressive rather than regressive effects. We believe that the variable mirrors governmental expenses for redistribution quite well. We further look at the public total social expenditure. The data are provided by the OECD's "Social Expenditure Dataset" (OECD 2012d). The variable measures the level of public expenditure of all types - cash benefits, in kind benefits/social services - of social measures. Obviously, social benefits are mainly contributed to the poorest fraction of the population; hence they are clearly expected to reduce income inequalities. The variables are available for almost all OECD countries in the period between 1980 and 2005.

While the first two variables measure the government expenditure side, the third variable of interest, degree of progressivity, looks at the government's revenue side. The data come from the World Tax Indicators (Sabirianova-Peter et al. 2010). This large and new panel data set covers personal income tax structures at the country level in 189 countries for the period 1981 to 2005 and contains various important variables such as average and marginal tax rates, progressivity or complexity. As a measure of progressivity, we select the average rate progression (ARP) variable. In all specifications employing ARP as the explanatory variable, we also control for the general level of taxation by including a variable for the top marginal income tax rate. This ensures that we identify the effect that directly stems from progressivity, rather than high tax rates. 
In order to facilitate the interpretation of our results, we use the logged values of the independent variables of interest in all our estimations. Together with logged inequality as the dependent variable, the coefficients allow an intuitive elasticity interpretation.

Control Variables We follow the literature and include a standard set of control variables into our estimations. From the "National Accounts" of the United Nations Statistics Division (United Nations 2012) we obtain variables for real GDP per capita (in constant 1990 US dollar prices) and openness to trade, measured as exports plus imports as a share of GDP (constant 1990 prices). Our estimations also control for squared GDP per capita in order to allow for non-linear effects of GDP on inequality (Kuznets 1955). ${ }^{9}$ The inflation rate and unemployment rate come from the OECD's "Main Economic Indicators" (OECD 2012b) and "Labor Force Statistics" (OECD 2012c), respectively. In order to control for the power of employees in wage bargaining, we use a measure of the net union density, measured as net union membership as a percentage of all wage earners, taken from the OECD employment database (OECD 2012a). Levels of higher education are accounted for by World Development Indicator (Worldbank 2012) data of tertiary school enrollment. At last, we include an index of globalization as developed and described by Dreher (2006).

Summary Statistics Table 3 in the Appendix provides summary statistics of all included variables. $N$ indicates the number of country-year observations for each variable. Over the time span of interest, we observe variation of inequality measures both within and between countries, where within variation is considerably smaller. The same holds true for our explanatory variables of interest and the controls. Our identification strategies will nevertheless solely exploit these within country variations. The statistics also reveal that the number of country-year observations differs across the measures of inequality as well as our explanatory variable. The following analyses try to maximize the number of observations. This has the drawback that each specification is based on a slightly different sample, depending on which variables are included, because the panel is highly unbalanced.

\footnotetext{
${ }^{9}$ Also see Acemoglu and Robinson (2002) for theoretical background.
} 


\subsection{Fixed Effects Panel Estimations}

\subsubsection{Identification Strategy}

Generally, we analyze our research question in a panel of OECD countries between 1981 and 2005. The regression equation that we estimate reads:

$$
Y_{i, t}=\beta_{1} x_{i, t-1}+\beta_{2} C_{i, t-1}+\gamma_{t}+\mu_{i}+\epsilon_{i, t}
$$

where $i$ denotes a country and $t$ the point of time. $x_{i, t-1}$ is one of the lagged policy variables of interest and $C_{i, t-1}$ is a vector of several lagged control variables. Time and country fixed effects are captured by $\gamma_{t}$ and $\mu_{i}$, respectively. $Y_{i, t}$ indicates the level of inequality. $\epsilon_{i, t}$ is a standard error term and our coefficient of interest is $\beta_{1}$.

In the Introduction we discussed the problem that policy measures are usually endogenous, requiring the researcher to control for any driving variables that shape both the policy of interest itself and the outcome variable. By estimating the model as in equation 1 we take several steps to overcome such problems of endogeneity. Firstly, we include a set of standard control variables that are believed to be confounding factors. Omitting these would lead to omitted variable bias and load onto the coefficients of our policy variables of interest. These control variables are discussed above and it does not require extensive explanations why we believe that they might affect both $Y$ and $x$. Despite the inclusion of these controls, there remains doubt whether all confounding variables are removed from $\epsilon$. This, secondly, motivates us to include a set of country fixed effects into our estimation. We thereby control for permanent differences across countries in the redistributional policies as well as inequality, and solely exploit within-country variation in our estimations. If the reverse causality mechanism is systematic within countries - i.e., if the way how levels of inequality affect redistributional policies is always similar across time within a country - , then these time invariant country characteristics and systematic channels are controlled for by the country fixed effects. That is, the country fixed effects approach ensures that we are able to control for any mechanism of reverse causality that is systematic within a country. Other time invariant confounding factors are controlled for as well. ${ }^{10}$ Our third step to identify unbiased effects is to include a set of year fixed effects, which account for any year specific effects and help us to control for spurious relations stemming from common trends in the variables on the left- and right-side of the equation. Fourthly, all our right-hand-side variables are lagged one year, so that we estimate the effect of redistributional policies in a year

\footnotetext{
${ }^{10}$ The country fixed effects also account for possible systematic and time invariant differences in the measurement of inequality.
} 
$t-1$ on inequality in year $t$. Such an approach further mitigates the problem of simultaneity bias caused by the fact that varying inequality levels also affect policies of redistribution. The estimated standard errors used for judging the statistical significance are cluster-adjusted for countries.

\subsubsection{Results and Discussion}

Table 1 displays the coefficients and results for the variables of interest, while detailed tables including all control variables can be found in Appendix A.3. Each panel in the Table presents the results for a different dataset to measure inequality. The results provide hints that within-country variation in the expenditure variables can explain varying levels of inequality, whereas progressive taxation seems to be less effective. The obtained coefficients are slightly different depending on the measure of inequality, indicating that data on economic inequality are inconsistently measured and barely comparable.

The coefficients of interests are to be interpreted in terms of elasticities. They display the percentage change in inequality in response to a $1 \%$ increase in the respective regressor. We are primarily interested in the coefficients of the policy variables government spending, social expenditure, and progressivity. Not all of these are precisely estimated and for some point estimates we obtain relatively large standard errors and confidence intervals, which do not allow a confidential rejection of the null hypotheses that the estimates are different from zero. However, as for precisely estimated coefficients, the signs point in the expected direction. The data suggest that redistributive measures of government expenditure are indeed able to achieve less inequality. Roughly speaking, a $1 \%$ increase in government spending or social expenditure decreases inequality by $0.3 \%$. The coefficient on tax progressivity is mostly insignificant, not allowing any clear conclusions. This might hint into the direction that higher tax progressivity triggers behavioral effects which tend to increase pre-tax inequality and hence offset the inequality reducing first-round effects (Poterba 2007).

Regarding the effects of the control variables (see Appendix A.3), we obtain results which are mostly in line with previous studies and intuition. Whereas withincountry variation in GDP or GDP-squared do not have significant effects on inequality, we find some weak evidence that inflation has a small negative effect. The estimations further show that union density has a strong and significantly negative impact on income inequality, suggesting that the variation in union density within countries over time has a significant impact on varying levels of the income distribution. 
Table 1: Fixed-Effects Panel Estimations

\begin{tabular}{|c|c|c|c|c|c|}
\hline \multicolumn{6}{|c|}{ Dependent Variable: Measure of Inequality } \\
\hline \multicolumn{6}{|c|}{ Panel A: LIS Gini } \\
\hline $\begin{array}{l}\text { Gov't Spending } \\
\text { (lagged) }\end{array}$ & $\begin{array}{c}-0.380^{* * *} \\
(0.120)\end{array}$ & $\begin{array}{c}-0.356^{* * *} \\
(0.108)\end{array}$ & & & \\
\hline Social Expenditure & & & $-0.232^{* *}$ & $-0.270^{* * *}$ & \\
\hline 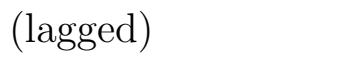 & & & $(0.092)$ & $(0.091)$ & \\
\hline Progressivity & & 0.007 & & $-0.132^{* *}$ & -0.015 \\
\hline (lagged) & & $(0.108)$ & & $(0.061)$ & $(0.097)$ \\
\hline Observations & 120 & 117 & 116 & 113 & 117 \\
\hline $\mathrm{R} 2$ & 0.546 & 0.545 & 0.564 & 0.588 & 0.515 \\
\hline \multicolumn{6}{|c|}{ Panel B: WIID Gini } \\
\hline $\begin{array}{l}\text { Gov't Spending } \\
\text { (lagged) }\end{array}$ & $\begin{array}{c}-0.307^{* *} \\
(0.113)\end{array}$ & $\begin{array}{l}-0.230^{* *} \\
(0.104)\end{array}$ & & & \\
\hline $\begin{array}{l}\text { Social Expenditure } \\
\text { (lagged) }\end{array}$ & & & $\begin{array}{l}-0.051 \\
(0.076)\end{array}$ & $\begin{array}{l}-0.023 \\
(0.080)\end{array}$ & \\
\hline Progressivity & & 0.041 & & 0.049 & 0.036 \\
\hline (lagged) & & $(0.046)$ & & $(0.045)$ & $(0.050)$ \\
\hline Observations & 368 & 351 & 349 & 338 & 351 \\
\hline $\mathrm{R} 2$ & 0.314 & 0.299 & 0.328 & 0.339 & 0.280 \\
\hline \multicolumn{6}{|c|}{ Panel C: UTIP Estimate } \\
\hline $\begin{array}{l}\text { Gov't Spending } \\
\text { (lagged) }\end{array}$ & $\begin{array}{l}-0.103 \\
(0.076)\end{array}$ & $\begin{array}{l}-0.081 \\
(0.090)\end{array}$ & & & \\
\hline $\begin{array}{l}\text { Social Expenditure } \\
\text { (lagged) }\end{array}$ & & & $\begin{array}{c}0.001 \\
(0.052)\end{array}$ & $\begin{array}{l}-0.004 \\
(0.054)\end{array}$ & \\
\hline Progressivity & & -0.025 & & -0.021 & -0.031 \\
\hline (lagged) & & $(0.025)$ & & $(0.026)$ & $(0.025)$ \\
\hline Observations & 437 & 389 & 378 & 353 & 389 \\
\hline $\mathrm{R} 2$ & 0.493 & 0.435 & 0.553 & 0.518 & 0.425 \\
\hline
\end{tabular}

[1] Explanatory Variables are lagged one year [2] All estimations contain lagged control variables [3] Country and Year Fixed Effects included [4] Standard errors in parentheses cluster adjusted for countries $[5] *<0.10, * *<0.05, * * *<0.01$ 
The models above, using both country and time fixed effects, yield some hints that redistributive policies can reduce inequality levels. However, due to possible remaining endogeneity and imprecise coefficients, we do not find clear-cut evidence that second-round effects do not offset redistributive policy measures - especially for progressive taxation. The estimated elasticities and confidence intervals differ depending on the employed dependent variable. This raises concerns about the general data quality (see the discussion in Section 2).

We must further be concerned that our identification strategy is not sufficient in order to obtain unbiased effects. The problem of reverse causality is not properly accounted for if the effect of inequality levels on redistribution policies is not systematic within countries. It might, for example, be the case that levels of inequality in a year $t-1$ affect policies in $t$ in a not systematic way, yielding the necessity to control for lagged levels of inequality. Doing so in the above framework would however not be legitimate.

One commonly used way of dealing with such dynamic problems is to include lagged levels of the dependent variable into the set of explanatory variable and estimate the equation using GMM methods as first suggested by Arellano and Bover (1995) and Blundell and Bond (1998), ${ }^{11}$ and applied in our context, e.g., by Calderon and Chong (2009). Unfortunately, however, these estimators are not appropriate for models with small $N$ and large $T$ like our panel (Roodman 2009; Roine et al. 2009). Another reason for GMM methods not to be applicable to our setting rests on our scepticism that the required assumption of "weak exogeneity" is met. The assumption of weak exogeneity allows the explanatory variables to be correlated with past and current levels of the error term, but not with its future realizations. There are reasons to believe that this assumption is barely justifiable in our setting. We have a reverse causality effect at hand, where redistribution does not only decrease inequality, but where inequality also positively affects levels of redistribution. Applying the assumption of weak exogeneity to our case implies that the system-GMM estimator, using internal instruments, would only be valid if future levels of inequality do not affect the current levels of the policy variables of interest: measures of redistribution. However, governments, that expect increasing inequality in the future, could implement redistributive measures to offset the anticipated shock on income inequality. Also, sticking with the logic of the Meltzer and Richard (1981) model, the median voter who expects rising levels of inequality in the future will vote for more redistribution. We are therefore skeptical that the assumption of weak exogeneity is likely to hold in our set-up.

\footnotetext{
${ }^{11}$ This approach builds on the first-difference GMM estimator originally proposed by Arellano and Bond (1991).
} 


\subsection{Instrumental Variable Approach}

Another possibility to deal with the obvious problem of endogeneity in our setting and to identify an unbiased effect is to find an instrumental variable (IV).

\subsubsection{Identification Strategy}

Our (second-stage) equation of interest is similar as in the previous section and reads

$$
Y_{i, t}=\beta_{3} x_{i, t}+\beta_{4} C_{i, t}+\gamma_{t}+\mu_{i}+\epsilon_{i, t},
$$

where $\beta_{3}$ is the coefficient of interest. As discussed above, we raise the concern that omitted variables in the error term might be correlated with our explanatory variables of interest, biasing the estimates. We employ instruments $z_{i, t}$ which are correlated to our respective measures of interest, but, conditioning on other variables, are not correlated with the dependent variable, i.e. $\operatorname{Cov}\left(z_{i, t}, \epsilon_{i, t}\right)=0$ and $\operatorname{Cov}\left(z_{i, t}, x_{i, t}\right) \neq 0$. We estimate the IV model using two stage least squares (2SLS). Our first-stage equation looks such as

$$
x_{i, t}=\delta_{1} z_{i, t}+\delta_{2} C_{i, t}+\gamma_{t}+\mu_{i}+\nu_{i, t}
$$

where we include the same control variables as well as country and year fixed effects as on the second-stage, and $\nu_{i, t}$ is a standard error term. The instrument $z$ must not affect $\epsilon$ after conditioning on the confounding variables in vector $C$ and the fixed effects $\gamma$ and $\mu$. We hence wish to exploit within-country variation in an instrument to identify our effect of interest, again hoping to control for any country systematic unobservable effects.

Finding suitable instruments is generally a difficult task. In our set-up, we require IVs that are independent of $\epsilon_{i, t}$ in equation 2 , but correlated with one of our three respective explanatory variables of interest (represented by $x_{i, t}$ : government spending, public total social expenditure, and degree of progressivity). An ideal instrument would be randomly assigned to each observation and therefore generate a quasi-experimental way to estimate the causal effect. Obviously, no such instrument is available in our setting with country-level observations. Policies or other variables that may be correlated with measures of redistribution are usually not randomly assigned to a country and thus mostly endogenous. We are not aware of any study that uses a randomly assigned instrument to identify the effect of policy variables on inequality.

In this paper, we use the initial levels of our policy variables as of 1981 and extrapolate them with the growth rate of GDP — for government spending and social 
expenditure - , and the growth rate of the highest marginal tax rate (MTR) - for the level of progressivity. The extrapolated figures are then used as instruments for the explanatory variables of interest. That is, our IVs take the initial value of the respective regressor in 1981 and then grow with the growth rate of GDP or the growth rate of the highest MTR. Our instruments are exogenous in the sense that we do not use the actual observed annual levels but extrapolated figures that are based on the initial levels in 1981. The instrument for one of the regressors may increase between two years within a country, whereas the actual level of the regressor remains stable. Though, we observe a strong correlation between the extrapolated numbers and the actual ones for our measures of government spending and social spending, hence satisfying the IV relevance requirement. For the exclusion restriction to hold, we have to assume that, conditional on our control variables and fixed effects, the inequality trends are uncorrelated with the (average) growth rates used for extrapolation. This can be justified because GDP and the top tax rate are, among other variables, controlled for on both stages of our estimation. We display first stage results at the bottom of our detailed tables in Section A.4 of the Appendix. ${ }^{12}$

\subsubsection{Results and Discussion}

Table 2 presents the coefficients of interest for our IV estimations. As seen before in section 4.2, our measures of government expenditure seem to have inequality reducing effects, whereas we find tax progressivity not to have a significant impact. Again, not all coefficients are sufficiently precise, but for those that are, we find that government spending and social expenditure compress the income distribution. A $1 \%$ increase in these two variables is approximately associated with a $0.3 \%$ drop in inequality. This confirms the pattern that we found in our previous analyses. The results for instrumented tax progressivity are not precisely estimated; thus not allowing any clear interpretation, but providing another hint that behavioral second-round effects play a stronger role with progressivity. The results regarding the control variables are presented in Appendix A.4 and are similar to the fixed effects models.

The results of the IV regressions rest on the assumption of instrument validity. That is, conditional on all control variables as well as the country and year fixed effects, the instruments must affect inequality only through the independent

\footnotetext{
${ }^{12}$ Angrist and Pischke (2009) note that insufficient first-stage results in exactly identified models do not do any harm except causing second-stage standard errors to be large. This is why we abstain from i) discussing the relevance of the instruments in detail and ii) only focus on sufficiently precise estimates in our interpretations of the results.
} 
Table 2: IV Estimations

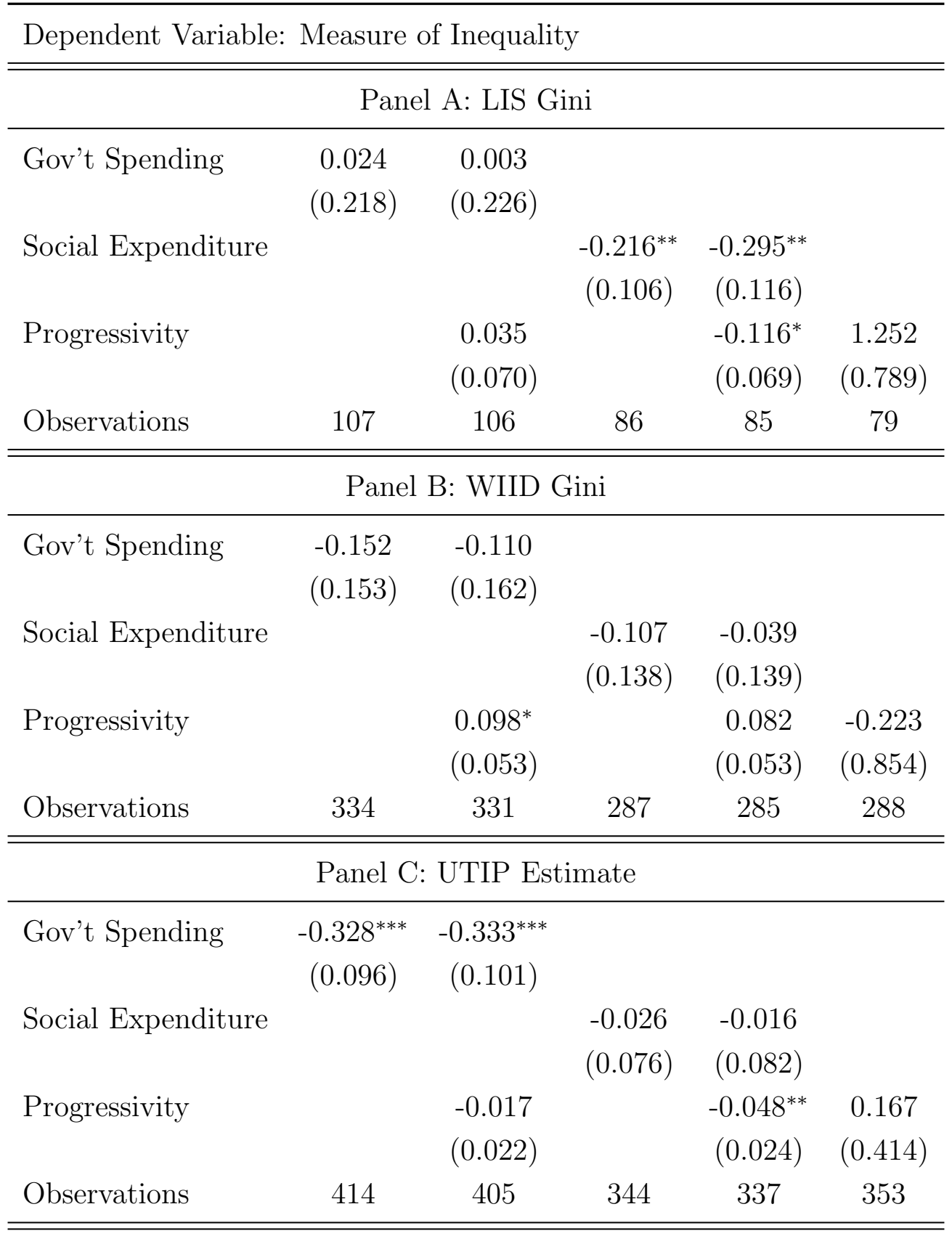

[1] 2SLS IV Estimations [2] IVs: Extrapolated Explanatory Variable

[3] All estimations contain control variables [4] Country and Year

Fixed Effects included [5] Standard errors in parentheses cluster adjusted for countries [6] $*<0.10, * *<0.05, * * *<0.01$ 
variables of interest. This assumption is untestable and its validity needs to be approached intuitively. Clearly, our instruments are not randomly assigned to each country-year observation and it is therefore difficult to claim that we are able to establish a causal relationship that is based on a quasi-experimental setup. However, as we extrapolate government spending and social expenditure in 1981 with the GDP growth rate and tax progressivity with the growth rate of the highest marginal tax rate to obtain our instruments, we are able to exploit some exogenous variation. The extrapolated values are not directly related to inequality. Of course, the growth rate of the GDP and marginal tax rate, which we use for extrapolation, have some impact on the income distribution, but we control for GDP and tax rate on both the first and second stage and hence condition on these variables. All our analyses contain not only year fixed-effects, but also country fixed effects. We thus exploit within-country variation in our instruments and control for any effects that are specific to the included countries and systematic across time.

The results are not entirely satisfying. Although we find negative coefficientsthat one would expect - in most specifications, the standard errors in some cases are large and imprecise, causing p-values and significance values to be high. In IV estimations, weak first-stage results can increase the standard errors on the secondstage, but this is mostly not the reason in our case; first-stage results are sufficiently strong at least for specifications which employ government spending and social expenditure as core explanatory variables. Negative coefficients estimated with more precision - that we obtain as well-, however, provide some evidence that first-round effects of redistributive expenditure policies can outweigh second-round effects and governments are indeed able to achieve inequality reduction.

\section{Conclusion}

This paper uses a panel of industrialized OECD countries over the time period between 1981 and 2005 to analyze the effect of redistributive policies on post-tax inequality. Using different data sources to measure inequality, the first part of this paper finds that the Gini coefficient has increased since the early 1980s, after a period of downwards trending inequality between the 1960s and 1980s. The observation that radical and liberal welfare states are characterized by more inequality than social-democratic or conservative ones provides a hint that institutions seem to matter for the income distribution. The large rise in inequality in Eastern European states since the breakdown of socialism in the late 80 s/early 90 s adds to this presumption. The analysis also shows that different data sources of the Gini coefficient display different levels as well as developments in inequality, suggesting that the use 
of empirical inequality measures may be critical and results might depend on the data source. This is confirmed in our regression analyses which find coefficients to differ both in terms of size and precision depending on which data source is used.

However, assuming that the data are consistently measured within one data source, the ordinal character of the data can be exploited to conduct multivariate analyses with inequality as the dependent variable. ${ }^{13}$ Exploiting this reasoning, the second part of this paper asks the question of whether redistributive policies significantly reduce inequality. We discuss potential sources of endogeneity and employ fixed effects and instrumental variable approaches to identify the effect of three policy variables of interest. Despite behavioral feedback effects, we provide some evidence that especially government spending and social expenditure meet their target of reducing post-government inequality as measured by the Gini coefficient. As for our precisely estimated coefficients, our different identification methods yield that a $1 \%$ increase in government spending or public social expenditure is roughly related to a $0.3 \%$ drop in inequality. Policies of government expenditure seem to matter more for reducing inequality than the degree of progressivity in the tax system. The insignificant results for the latter might hint into the direction that higher tax progressivity indeed exhibits (stronger) behavioral effects, which tend to increase pre-tax inequality and hence countervail the inequality reducing direct effects (Poterba 2007). Our results show that inequality reduction is more effectively achieved through measures of expenditure as opposed to taxation. Hence, given the disincentive and distorting effects of progressive taxation, our results might imply that governments should combat inequality through policies on the expenditure side rather than increasing the progressivity of the tax system. Our findings might also help explaining observed differences in inequality between European countries and the US. While the US has one of the most progressive income taxes in the world, very little redistribution is conducted through social benefits. In contrast, European welfare states rely (on average) much more on benefits and government expenditure to fight inequality.

The difficulties of identifying a clear and clean causal effect are omnipresent and inherent to this literature. Scholars would require either a field experiment or good quasi-experimental design to obtain a clear-cut causal picture. Obviously - and this problem is underlying almost all, if not all, country-level studies - it is nearly impossible to exploit such an identification strategy, i.e., to randomly assign redistributive policies to a set of countries. We identify possible sources of endogeneity in our setting and take several steps to overcome it. The Fixed Effects and IV meth-

\footnotetext{
${ }^{13}$ This is inherent to many other data sources, in which cardinal measurement is critical to assume. See for example the discussion on happiness research in Frey and Stutzer (2002).
} 
ods used here can certainly mitigate problems of endogeneity, but there remains doubt if they are sufficient. Looking at single policy changes in redistribution (the "treatment"), Difference-in-Difference (DiD) analyses may help to identify a clear effect. Though, the required "common trend" assumption across both countries is often difficult to defend. Abadie and Gardeazabal (2003) and Abadie et al. (2010) recently proposed a new approach based on a "synthetic" counterfactual country (region). The method uses a combination of other countries (regions) on similar pre-treatment characteristics to run an analysis similar to DiD, where the matched synthetic country serves as the counterfactual. However, in terms of the research question imposed in this paper, $\mathrm{DiD}$ and synthetic-country approaches are not appropriate because we do not look at the effect of one particular policy change on inequality. System-GMM methods may also be able to handle some of the inherent problems of endogeneity, but require very rich data, which are often not available, and are highly sensitive to specification and the choice of internal instruments. Additionally, in many set-ups - including ours - System-GMM methods are not eligible due to panel structures with small $N$ and large $T$ or due to the failure to assume "weak exogeneity".

Considering the political importance and widely held debates about (increasing) inequality around the world, the research question imposed in our paper needs further attention. Policy makers heavily rely on researchers and their analyses when considering different measures of reducing inequality. Therefore, it is important that the issue of causal identification will be further approached in future research. Quasi-experimental methods such as good IVs, stemming from random processes, or DiD methods, looking at single policy measures, are a promising path. 


\section{A Appendix}

\section{A.1 Development of Inequality over time}

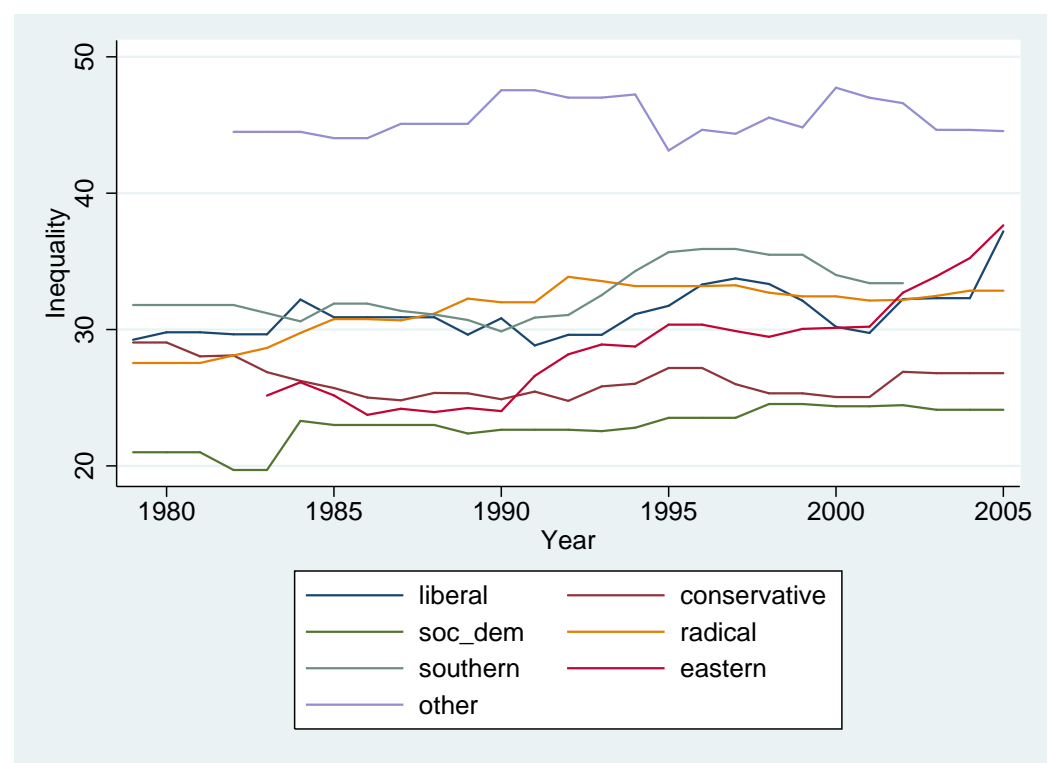

Figure 3: Inequality (lis) by welfare types

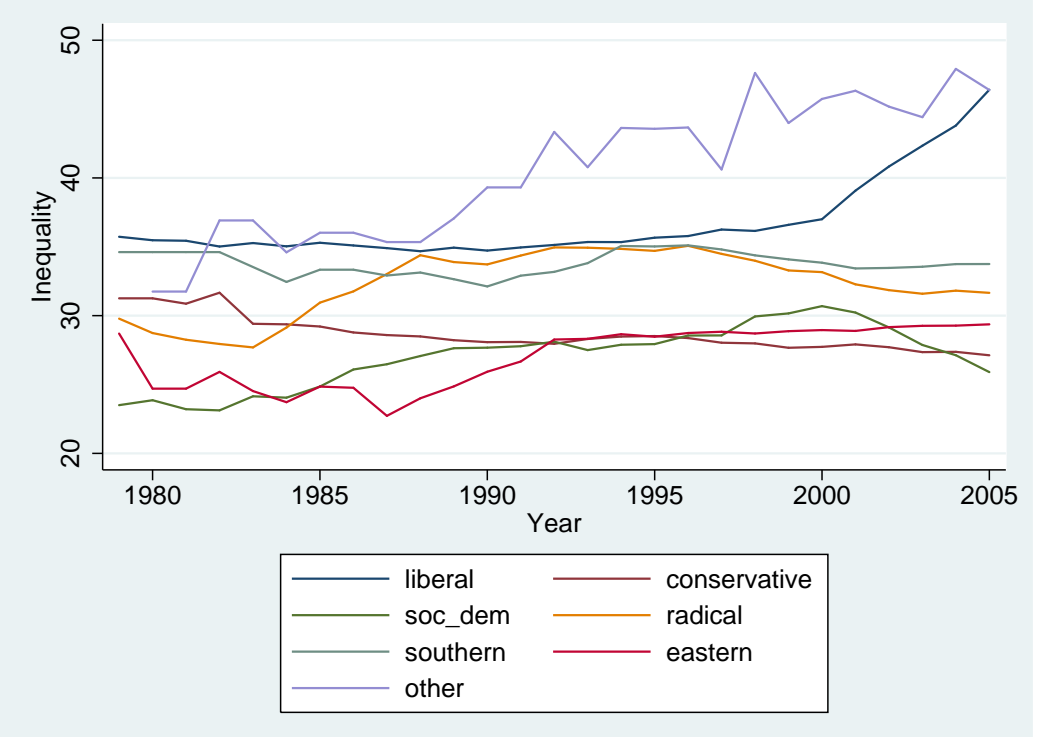

Figure 4: Inequality (uw) by welfare types

\section{A.2 Summary Statistics}


Table 3: Summary Statistics

\begin{tabular}{|c|c|c|c|c|}
\hline Variable & & Mean & Std. Dev. & Obs \\
\hline \multirow[t]{3}{*}{ LIS Gini } & overall & 30.34583 & 7.142591 & $\mathrm{~N}=159$ \\
\hline & between & & 6.288292 & $\mathrm{n}=29$ \\
\hline & within & & 2.587905 & $\mathrm{~T}=5.48276$ \\
\hline \multirow[t]{3}{*}{ WIID Gini } & overall & 30.7561 & 6.026748 & $\mathrm{~N}=448$ \\
\hline & between & & 5.885699 & $\mathrm{n}=28$ \\
\hline & within & & 2.65283 & $\mathrm{~T}=16$ \\
\hline \multirow[t]{3}{*}{ UTIP Ineq } & overall & 35.34152 & 4.735462 & $\mathrm{~N}=580$ \\
\hline & between & & 4.171345 & $\mathrm{n}=28$ \\
\hline & within & & 2.434937 & $\mathrm{~T}=20.7143$ \\
\hline \multirow[t]{3}{*}{ Govt Spending } & overall & $8.16 \mathrm{e}+10$ & $1.33 \mathrm{e}+11$ & $\mathrm{~N}=848$ \\
\hline & between & & $1.32 \mathrm{e}+11$ & $\mathrm{n}=30$ \\
\hline & within & & $2.67 \mathrm{e}+10$ & $\mathrm{~T}=28.2667$ \\
\hline \multirow[t]{3}{*}{ Social Exp } & overall & $1.24 \mathrm{e}+11$ & $2.13 \mathrm{e}+11$ & $\mathrm{~N}=670$ \\
\hline & between & & $2.00 \mathrm{e}+11$ & $\mathrm{n}=30$ \\
\hline & within & & $6.55 \mathrm{e}+10$ & $\mathrm{~T}=22.3333$ \\
\hline \multirow[t]{3}{*}{ ARP overall } & overall & .0753014 & .0243012 & $\mathrm{~N}=697$ \\
\hline & between & & .0208241 & $\mathrm{n}=30$ \\
\hline & within & & .0133746 & $\mathrm{~T}=23.2333$ \\
\hline \multirow[t]{3}{*}{ Toprate } & overall & 44.63314 & 14.55172 & $\mathrm{~N}=717$ \\
\hline & between & & 11.72463 & $\mathrm{n}=30$ \\
\hline & within & & 8.618669 & $\mathrm{~T}=23.9$ \\
\hline \multirow[t]{3}{*}{ Educ } & overall & 42.80875 & 20.99698 & $\mathrm{~N}=759$ \\
\hline & between & & 13.80687 & $\mathrm{n}=28$ \\
\hline & within & & 17.03499 & $\mathrm{~T}=27.1071$ \\
\hline \multirow[t]{3}{*}{ GDP p. capita } & overall & 18500.42 & 10677.75 & $\mathrm{~N}=848$ \\
\hline & between & & 10181.31 & $\mathrm{n}=30$ \\
\hline & within & & 4090.34 & $\mathrm{~T}=28.2667$ \\
\hline \multirow[t]{3}{*}{ Inflation } & overall & 9.100438 & 24.17119 & $\mathrm{~N}=849$ \\
\hline & between & & 12.25823 & $\mathrm{n}=30$ \\
\hline & within & & 21.17695 & $\mathrm{~T}=28.3$ \\
\hline \multirow[t]{3}{*}{ Trade } & overall & 84.80983 & 53.20028 & $\mathrm{~N}=848$ \\
\hline & between & & 46.59816 & $\mathrm{n}=30$ \\
\hline & within & & 29.29007 & $\mathrm{~T}=28.2667$ \\
\hline
\end{tabular}




\begin{tabular}{|c|c|c|c|c|}
\hline \multirow{4}{*}{ Unemployment } & \multicolumn{4}{|c|}{ continued from previous page } \\
\hline & overall & 7.16477 & 4.27503 & $\mathrm{~N}=738$ \\
\hline & between & & 3.806607 & $\mathrm{n}=30$ \\
\hline & within & & 2.306527 & $\mathrm{~T}=24.6$ \\
\hline \multirow[t]{3}{*}{ Union } & overall & 38.69974 & 21.5432 & $\mathrm{~N}=755$ \\
\hline & between & & 20.13219 & $\mathrm{n}=30$ \\
\hline & within & & 7.329944 & $\mathrm{~T}=25.1667$ \\
\hline \multirow[t]{3}{*}{ Globalization } & overall & 72.1562 & 12.95818 & $\mathrm{~N}=800$ \\
\hline & between & & 10.25295 & $\mathrm{n}=30$ \\
\hline & within & & 7.867985 & $\mathrm{~T}=26.6667$ \\
\hline
\end{tabular}

\section{A.3 Fixed Effects Panel Models (including control variables)}

Table 4: Dependent Variable LIS Gini

\begin{tabular}{|c|c|c|c|c|c|}
\hline & Gini & Gini & Gini & Gini & Gini \\
\hline Gov't Spending & $\begin{array}{c}-0.380^{* * *} \\
(0.120)\end{array}$ & $\begin{array}{c}-0.356^{* * *} \\
(0.108)\end{array}$ & & & \\
\hline Social Expenditure & & & $\begin{array}{c}-0.232^{* *} \\
(0.092)\end{array}$ & $\begin{array}{c}-0.270^{* * *} \\
(0.091)\end{array}$ & \\
\hline Progressivity & & $\begin{array}{c}0.007 \\
(0.108)\end{array}$ & & $\begin{array}{c}-0.132^{* *} \\
(0.061)\end{array}$ & $\begin{array}{r}-0.015 \\
(0.097)\end{array}$ \\
\hline Top Tax Rate & & $\begin{array}{c}0.001 \\
(0.002)\end{array}$ & & $\begin{array}{c}0.003^{*} \\
(0.002)\end{array}$ & $\begin{array}{c}0.002 \\
(0.002)\end{array}$ \\
\hline School enrollment & $\begin{array}{c}0.000 \\
(0.001)\end{array}$ & $\begin{array}{c}0.000 \\
(0.001)\end{array}$ & $\begin{array}{c}0.001 \\
(0.001)\end{array}$ & $\begin{array}{c}0.001 \\
(0.001)\end{array}$ & $\begin{array}{c}0.000 \\
(0.001)\end{array}$ \\
\hline Real GDP p.c. & $\begin{array}{l}0.000^{* *} \\
(0.000)\end{array}$ & $\begin{array}{c}0.000^{*} \\
(0.000)\end{array}$ & $\begin{array}{c}0.000 \\
(0.000)\end{array}$ & $\begin{array}{c}0.000 \\
(0.000)\end{array}$ & $\begin{array}{c}0.000 \\
(0.000)\end{array}$ \\
\hline GDP squared & $\begin{array}{r}-0.000 \\
(0.000)\end{array}$ & $\begin{array}{r}-0.000 \\
(0.000)\end{array}$ & $\begin{array}{r}-0.000 \\
(0.000)\end{array}$ & $\begin{array}{r}-0.000 \\
(0.000)\end{array}$ & $\begin{array}{r}-0.000 \\
(0.000)\end{array}$ \\
\hline Inflation & $\begin{array}{c}-0.003^{*} \\
(0.002)\end{array}$ & $\begin{array}{c}-0.003 \\
(0.002)\end{array}$ & $\begin{array}{c}-0.003^{*} \\
(0.002)\end{array}$ & $\begin{array}{c}-0.005^{* *} \\
(0.002)\end{array}$ & $\begin{array}{r}-0.003 \\
(0.002)\end{array}$ \\
\hline Openness to Trade & $\begin{array}{r}-0.001 \\
(0.001)\end{array}$ & $\begin{array}{r}-0.001 \\
(0.001)\end{array}$ & $\begin{array}{r}-0.000 \\
(0.001)\end{array}$ & $\begin{array}{r}-0.001 \\
(0.001)\end{array}$ & $\begin{array}{r}-0.001 \\
(0.001)\end{array}$ \\
\hline Unemployment rate & $\begin{array}{c}0.011^{*} \\
(0.006)\end{array}$ & $\begin{array}{c}0.011^{*} \\
(0.006)\end{array}$ & $\begin{array}{c}0.008 \\
(0.007)\end{array}$ & $\begin{array}{c}0.009 \\
(0.007)\end{array}$ & $\begin{array}{c}0.008 \\
(0.007)\end{array}$ \\
\hline Union density & $\begin{array}{c}-0.004 \\
(0.003)\end{array}$ & $\begin{array}{r}-0.004 \\
(0.003)\end{array}$ & $\begin{array}{c}-0.003^{*} \\
(0.002)\end{array}$ & $\begin{array}{r}-0.002 \\
(0.002)\end{array}$ & $\begin{array}{r}-0.002 \\
(0.003)\end{array}$ \\
\hline Globalization & $\begin{array}{c}0.001 \\
(0.004)\end{array}$ & $\begin{array}{c}0.001 \\
(0.004)\end{array}$ & $\begin{array}{r}-0.002 \\
(0.004)\end{array}$ & $\begin{array}{c}0.000 \\
(0.004)\end{array}$ & $\begin{array}{c}0.002 \\
(0.005)\end{array}$ \\
\hline constant & $11.963^{* * *}$ & $11.335^{* * *}$ & $9.145^{* * *}$ & $\begin{array}{c}9.336^{* * *} \\
\text { continues }\end{array}$ & $\begin{array}{l}2.756^{* * *} \\
n \text { next page }\end{array}$ \\
\hline
\end{tabular}




\begin{tabular}{lccccc} 
& & & \multicolumn{3}{c}{ continued from previous page } \\
$\mathrm{N}$ & $(2.976)$ & $(2.793)$ & $(2.363)$ & $(2.513)$ & $(0.805)$ \\
$\mathrm{R} 2$ & 120 & 117 & 116 & 113 & 117 \\
\hline \hline
\end{tabular}

[1] Dependent Var: LIS Gini [2] All Explanatory Variables lagged one year [3] Country and year fixed effects in all specifications [4] Standard errors cluster adjusted for country

$[5] *<0.10, * *<0.05, * * *<0.01$

Table 5: Dependent Variable WIID Gini

\begin{tabular}{|c|c|c|c|c|c|}
\hline & Gini & Gini & Gini & Gini & Gini \\
\hline \multirow[t]{2}{*}{ Gov't Spending } & $-0.307^{* *}$ & $-0.230^{* *}$ & & & \\
\hline & $(0.113)$ & $(0.104)$ & & & \\
\hline \multirow[t]{2}{*}{ Social Expenditure } & & & -0.051 & -0.023 & \\
\hline & & & $(0.076)$ & $(0.080)$ & \\
\hline \multirow[t]{2}{*}{ Progressivity } & & 0.041 & & 0.049 & 0.036 \\
\hline & & $(0.046)$ & & $(0.045)$ & $(0.050)$ \\
\hline \multirow[t]{2}{*}{ Top Tax Rate } & & -0.002 & & -0.002 & -0.002 \\
\hline & & $(0.002)$ & & $(0.002)$ & $(0.002)$ \\
\hline \multirow[t]{2}{*}{ School enrollment } & -0.000 & -0.000 & 0.000 & 0.000 & -0.000 \\
\hline & $(0.001)$ & $(0.001)$ & $(0.001)$ & $(0.001)$ & $(0.001)$ \\
\hline \multirow[t]{2}{*}{ Real GDP p.c. } & -0.000 & -0.000 & -0.000 & -0.000 & -0.000 \\
\hline & $(0.000)$ & $(0.000)$ & $(0.000)$ & $(0.000)$ & $(0.000)$ \\
\hline \multirow[t]{2}{*}{ GDP squared } & 0.000 & 0.000 & 0.000 & 0.000 & 0.000 \\
\hline & $(0.000)$ & $(0.000)$ & $(0.000)$ & $(0.000)$ & $(0.000)$ \\
\hline \multirow[t]{2}{*}{ Inflation } & $-0.000^{* * *}$ & $-0.000^{* * *}$ & $-0.000^{* * *}$ & $-0.000^{* * *}$ & $-0.000^{* * *}$ \\
\hline & $(0.000)$ & $(0.000)$ & $(0.000)$ & $(0.000)$ & $(0.000)$ \\
\hline \multirow[t]{2}{*}{ Openness to Trade } & 0.000 & 0.000 & -0.000 & -0.000 & 0.000 \\
\hline & $(0.001)$ & $(0.001)$ & $(0.001)$ & $(0.001)$ & $(0.001)$ \\
\hline \multirow[t]{2}{*}{ Unemployment rate } & 0.001 & 0.001 & 0.004 & 0.004 & -0.000 \\
\hline & $(0.004)$ & $(0.004)$ & $(0.004)$ & $(0.004)$ & $(0.005)$ \\
\hline \multirow[t]{2}{*}{ Union density } & -0.001 & -0.001 & -0.000 & -0.000 & -0.000 \\
\hline & $(0.001)$ & $(0.001)$ & $(0.001)$ & $(0.001)$ & $(0.001)$ \\
\hline \multirow[t]{2}{*}{ Globalization } & $0.006^{*}$ & 0.005 & 0.004 & 0.004 & 0.005 \\
\hline & $(0.003)$ & $(0.003)$ & $(0.004)$ & $(0.003)$ & $(0.004)$ \\
\hline \multirow[t]{2}{*}{ constant } & $10.402^{* * *}$ & $8.828^{* * *}$ & $4.292^{* *}$ & $3.960^{* *}$ & $3.556^{* * *}$ \\
\hline & $(2.580)$ & $(2.436)$ & $(1.744)$ & $(1.826)$ & $(0.363)$ \\
\hline $\mathrm{N}$ & 368 & 351 & 349 & 338 & 351 \\
\hline $\mathrm{R} 2$ & 0.314 & 0.299 & 0.328 & 0.339 & 0.280 \\
\hline
\end{tabular}

[1] Dependent Var: WIID Gini [2] All Explanatory Variables lagged one year [3] Country and year fixed effects in all specifications [4] Standard errors cluster adjusted for country

$[5] *<0.10, * *<0.05, * * *<0.01$ 
Table 6: Dependent Variable UTIP estimate

\begin{tabular}{|c|c|c|c|c|c|}
\hline & UTIP & $U T I P$ & $U T I P$ & UTIP & UTIP \\
\hline \multirow[t]{2}{*}{ Gov't Spending } & -0.103 & -0.081 & & & \\
\hline & $(0.076)$ & $(0.090)$ & & & \\
\hline \multirow[t]{2}{*}{ Social Expenditure } & & & 0.001 & -0.004 & \\
\hline & & & $(0.052)$ & $(0.054)$ & \\
\hline \multirow[t]{2}{*}{ Progressivity } & & -0.025 & & -0.021 & -0.031 \\
\hline & & $(0.025)$ & & $(0.026)$ & $(0.025)$ \\
\hline \multirow[t]{2}{*}{ Top Tax Rate } & & 0.000 & & 0.000 & 0.000 \\
\hline & & $(0.001)$ & & $(0.001)$ & $(0.001)$ \\
\hline \multirow[t]{2}{*}{ School enrollment } & 0.000 & 0.000 & 0.000 & 0.000 & 0.000 \\
\hline & $(0.000)$ & $(0.000)$ & $(0.000)$ & $(0.000)$ & $(0.000)$ \\
\hline \multirow[t]{2}{*}{ Real GDP p.c. } & $0.000^{*}$ & 0.000 & $0.000^{*}$ & $0.000^{*}$ & 0.000 \\
\hline & $(0.000)$ & $(0.000)$ & $(0.000)$ & $(0.000)$ & $(0.000)$ \\
\hline \multirow[t]{2}{*}{ GDP squared } & -0.000 & -0.000 & $-0.000^{* *}$ & $-0.000^{* *}$ & -0.000 \\
\hline & $(0.000)$ & $(0.000)$ & $(0.000)$ & $(0.000)$ & $(0.000)$ \\
\hline \multirow[t]{2}{*}{ Inflation } & -0.000 & -0.000 & $-0.000^{* * *}$ & $-0.000^{* * *}$ & -0.000 \\
\hline & $(0.000)$ & $(0.000)$ & $(0.000)$ & $(0.000)$ & $(0.000)$ \\
\hline \multirow[t]{2}{*}{ Openness to Trade } & 0.000 & 0.000 & -0.000 & -0.000 & 0.000 \\
\hline & $(0.000)$ & $(0.000)$ & $(0.000)$ & $(0.000)$ & $(0.000)$ \\
\hline \multirow[t]{2}{*}{ Unemployment rate } & $0.004^{* *}$ & 0.003 & 0.003 & 0.002 & 0.002 \\
\hline & $(0.002)$ & $(0.003)$ & $(0.002)$ & $(0.003)$ & $(0.002)$ \\
\hline \multirow[t]{2}{*}{ Union density } & $-0.004^{* * *}$ & $-0.003^{* *}$ & $-0.002^{* *}$ & -0.002 & $-0.003^{* *}$ \\
\hline & $(0.001)$ & $(0.001)$ & $(0.001)$ & $(0.001)$ & $(0.001)$ \\
\hline \multirow[t]{2}{*}{ Globalization } & -0.000 & -0.000 & -0.002 & -0.001 & -0.001 \\
\hline & $(0.003)$ & $(0.003)$ & $(0.002)$ & $(0.003)$ & $(0.003)$ \\
\hline \multirow[t]{2}{*}{ constant } & $5.935 * * *$ & $5.303^{* *}$ & $3.486^{* *}$ & $3.448^{* *}$ & $3.480^{* * *}$ \\
\hline & $(1.830)$ & $(2.192)$ & $(1.282)$ & $(1.472)$ & $(0.354)$ \\
\hline $\mathrm{N}$ & 437 & 389 & 378 & 353 & 389 \\
\hline $\mathrm{R} 2$ & 0.493 & 0.435 & 0.553 & 0.518 & 0.425 \\
\hline
\end{tabular}

[1] Dependent Var: UTIP Estimate [2] All Explanatory Variables lagged one year [3] Country and year fixed effects in all specifications [4] Standard errors cluster adjusted for country

$[5] *<0.10, * *<0.05, * * *<0.01$

\section{A.4 IV Models (including control variables and first-stage results)}


Table 7: Dependent Variable LIS Gini

\begin{tabular}{|c|c|c|c|c|c|}
\hline & Gini & Gini & Gini & Gini & Gini \\
\hline \multirow[t]{2}{*}{ Gov't Spending } & 0.024 & 0.003 & & & \\
\hline & $(0.218)$ & $(0.226)$ & & & \\
\hline \multirow[t]{2}{*}{ Social Expenditure } & & & $-0.216^{* *}$ & $-0.295^{* *}$ & \\
\hline & & & $(0.106)$ & $(0.116)$ & \\
\hline \multirow[t]{2}{*}{ Progressivity } & & 0.035 & & $-0.116^{*}$ & 1.252 \\
\hline & & $(0.070)$ & & $(0.069)$ & $(0.789)$ \\
\hline \multirow[t]{2}{*}{ Top Tax Rate } & & $-0.006^{* *}$ & & -0.001 & $-0.029 * *$ \\
\hline & & $(0.002)$ & & $(0.003)$ & $(0.013)$ \\
\hline \multirow[t]{2}{*}{ School enrollment } & -0.001 & -0.002 & 0.001 & 0.001 & 0.001 \\
\hline & $(0.001)$ & $(0.001)$ & $(0.001)$ & $(0.001)$ & $(0.002)$ \\
\hline \multirow[t]{2}{*}{ Real GDP p.c. } & 0.000 & 0.000 & 0.000 & 0.000 & -0.000 \\
\hline & $(0.000)$ & $(0.000)$ & $(0.000)$ & $(0.000)$ & $(0.000)$ \\
\hline \multirow[t]{2}{*}{ GDP squared } & -0.000 & 0.000 & -0.000 & -0.000 & 0.000 \\
\hline & $(0.000)$ & $(0.000)$ & $(0.000)$ & $(0.000)$ & $(0.000)$ \\
\hline \multirow[t]{2}{*}{ Inflation } & -0.002 & -0.001 & $0.005^{*}$ & -0.003 & $0.036^{*}$ \\
\hline & $(0.002)$ & $(0.003)$ & $(0.003)$ & $(0.006)$ & $(0.021)$ \\
\hline \multirow[t]{2}{*}{ Openness to Trade } & -0.001 & -0.001 & $-0.001^{*}$ & $-0.001^{* *}$ & -0.003 \\
\hline & $(0.001)$ & $(0.001)$ & $(0.001)$ & $(0.001)$ & $(0.002)$ \\
\hline \multirow[t]{2}{*}{ Unemployment rate } & 0.006 & 0.006 & 0.004 & 0.005 & 0.002 \\
\hline & $(0.004)$ & $(0.004)$ & $(0.005)$ & $(0.005)$ & $(0.011)$ \\
\hline \multirow[t]{2}{*}{ Union density } & $-0.004^{* *}$ & $-0.005^{* *}$ & -0.001 & -0.000 & -0.005 \\
\hline & $(0.002)$ & $(0.002)$ & $(0.002)$ & $(0.002)$ & $(0.005)$ \\
\hline \multirow[t]{2}{*}{ Globalization } & $0.012^{* *}$ & $0.011^{*}$ & -0.002 & -0.002 & -0.011 \\
\hline & $(0.006)$ & $(0.006)$ & $(0.004)$ & $(0.004)$ & $(0.014)$ \\
\hline $\mathrm{N}$ & 107 & 106 & 86 & 85 & 79 \\
\hline \multicolumn{6}{|l|}{ First-stage results } \\
\hline \multirow[t]{2}{*}{ Coefficient IV } & $0.024^{* *}$ & $0.024^{* *}$ & $0.042^{* * *}$ & $0.037 * * *$ & -0.175 \\
\hline & $(0.010)$ & $(0.010)$ & $(0.007)$ & $(0.007)$ & $(0.294)$ \\
\hline F-Statistic & 5.51 & 6.39 & 35.37 & 29.15 & 1.17 \\
\hline
\end{tabular}

[1] Dependent Var: LIS Gini [2] 2SLS IV Estimations [3] IVs are extrapoltaed values of core expl. variables [4] First-stage results display coefficients in first-stage regressions of instrumented var on IV [5] Country and year fixed effects in all specifications [6] Standard errors cluster adjusted for countries [6] $*<0.10, * *<0.05, * * *<0.01$

Table 8: Dependent Variable WIID Gini

\begin{tabular}{lccccc}
\hline \hline & Gini & Gini & Gini & Gini & Gini \\
\hline Gov't Spending & -0.152 & -0.110 & & \\
& $(0.153)$ & $(0.162)$ & & \\
Social Expenditure & & & -0.107 & -0.039 \\
& & & $(0.138)$ & $(0.139)$ & \\
& & & continues on next page
\end{tabular}




\begin{tabular}{|c|c|c|c|c|c|}
\hline \multirow[b]{2}{*}{ Progressivity } & & \multirow[b]{2}{*}{$0.098^{*}$} & & \multicolumn{2}{|c|}{ continued from previous pag } \\
\hline & & & & 0.082 & -0.223 \\
\hline & & $(0.053)$ & & $(0.053)$ & $(0.854)$ \\
\hline \multirow[t]{2}{*}{ Top Tax Rate } & & -0.002 & & -0.002 & 0.003 \\
\hline & & $(0.002)$ & & $(0.002)$ & $(0.015)$ \\
\hline \multirow[t]{2}{*}{ School enrollment } & -0.001 & -0.001 & -0.000 & -0.001 & -0.000 \\
\hline & $(0.001)$ & $(0.001)$ & $(0.001)$ & $(0.001)$ & $(0.002)$ \\
\hline \multirow[t]{2}{*}{ Real GDP p.c. } & -0.000 & -0.000 & -0.000 & -0.000 & -0.000 \\
\hline & $(0.000)$ & $(0.000)$ & $(0.000)$ & $(0.000)$ & $(0.000)$ \\
\hline \multirow[t]{2}{*}{ GDP squared } & 0.000 & 0.000 & 0.000 & 0.000 & 0.000 \\
\hline & $(0.000)$ & $(0.000)$ & $(0.000)$ & $(0.000)$ & $(0.000)$ \\
\hline \multirow[t]{2}{*}{ Inflation } & $-0.003^{* *}$ & -0.002 & 0.001 & 0.001 & 0.004 \\
\hline & $(0.002)$ & $(0.002)$ & $(0.005)$ & $(0.005)$ & $(0.008)$ \\
\hline \multirow[t]{2}{*}{ Openness to Trade } & -0.000 & 0.000 & -0.001 & -0.001 & -0.001 \\
\hline & $(0.001)$ & $(0.001)$ & $(0.001)$ & $(0.001)$ & $(0.001)$ \\
\hline \multirow[t]{2}{*}{ Unemployment rate } & 0.000 & -0.000 & -0.000 & -0.001 & -0.006 \\
\hline & $(0.004)$ & $(0.004)$ & $(0.004)$ & $(0.004)$ & $(0.009)$ \\
\hline \multirow[t]{2}{*}{ Union density } & -0.000 & -0.001 & 0.001 & 0.001 & 0.004 \\
\hline & $(0.002)$ & $(0.002)$ & $(0.002)$ & $(0.002)$ & $(0.011)$ \\
\hline \multirow[t]{2}{*}{ Globalization } & 0.006 & 0.006 & 0.007 & 0.006 & 0.009 \\
\hline & $(0.004)$ & $(0.005)$ & $(0.005)$ & $(0.005)$ & $(0.006)$ \\
\hline $\mathrm{N}$ & 334 & 331 & 287 & 285 & 288 \\
\hline \multicolumn{6}{|l|}{ First-stage results } \\
\hline \multirow[t]{2}{*}{ Coefficient IV } & $0.017^{* * *}$ & $0.016^{* * *}$ & $0.036^{* * *}$ & $0.035^{* * *}$ & 0.252 \\
\hline & $(0.003)$ & $(0.003)$ & $(0.005)$ & $(0.004)$ & $(0.158)$ \\
\hline F-Statistic & 33.10 & 40.56 & 56.78 & 76.88 & 2.56 \\
\hline
\end{tabular}

[1] Dependent Var: WIID Gini [2] 2SLS IV Estimations [3] IVs are extrapoltaed values of core expl. variables [4] First-stage results display coefficients in first-stage regressions of instrumented var on IV [5] Country and year fixed effects in all specifications [6] Standard errors cluster adjusted for countries [6] $*<0.10, * *<0.05, * * *<0.01$

Table 9: Dependent Variable UTIP

\begin{tabular}{lccccc}
\hline \hline & UTIP & UTIP & UTIP & UTIP & UTIP \\
\hline Gov't Spending & $-0.328^{* * *}$ & $-0.333^{* * *}$ & & & \\
& $(0.096)$ & $(0.101)$ & & & \\
Social Expenditure & & & -0.026 & -0.016 & \\
& & $(0.076)$ & $(0.082)$ & \\
Progressivity & & & $-0.048^{* *}$ & 0.167 \\
& & -0.017 & & $(0.024)$ & $(0.414)$ \\
Top Tax Rate & & $0.022)$ & & 0.000 & -0.003 \\
& & -0.000 & & $(0.001)$ & $(0.006)$ \\
School enrollment & $0.001^{* * *}$ & $0.001^{* * *}$ & $0.001^{*}$ & $0.001^{* *}$ & 0.000 \\
& $(0.000)$ & $(0.000)$ & $(0.000)$ & $(0.000)$ & $(0.001)$ \\
& & & & continues on next page
\end{tabular}




\begin{tabular}{|c|c|c|c|c|c|}
\hline \multirow[b]{2}{*}{ Real GDP p.c. } & \multirow[b]{2}{*}{$0.000^{* * *}$} & \multirow[b]{2}{*}{$0.000^{* * *}$} & \multicolumn{3}{|c|}{ continued from previous pag } \\
\hline & & & $0.000 * *$ & $0.000 * * *$ & -0.000 \\
\hline & $(0.000)$ & $(0.000)$ & $(0.000)$ & $(0.000)$ & $(0.000)$ \\
\hline \multirow[t]{2}{*}{ GDP squared } & $-0.000^{* *}$ & $-0.000^{* *}$ & $-0.000^{* * *}$ & $-0.000^{* * *}$ & 0.000 \\
\hline & $(0.000)$ & $(0.000)$ & $(0.000)$ & $(0.000)$ & $(0.000)$ \\
\hline \multirow[t]{2}{*}{ Inflation } & $-0.000^{* *}$ & $-0.000^{*}$ & $0.003^{* *}$ & $0.003^{* *}$ & 0.002 \\
\hline & $(0.000)$ & $(0.000)$ & $(0.001)$ & $(0.001)$ & $(0.002)$ \\
\hline \multirow[t]{2}{*}{ Openness to Trade } & 0.000 & 0.000 & 0.000 & 0.000 & 0.001 \\
\hline & $(0.000)$ & $(0.000)$ & $(0.000)$ & $(0.000)$ & $(0.001)$ \\
\hline \multirow[t]{2}{*}{ Unemployment rate } & $0.005^{* *}$ & $0.005^{* *}$ & $0.005^{* *}$ & $0.004^{*}$ & 0.003 \\
\hline & $(0.002)$ & $(0.002)$ & $(0.002)$ & $(0.002)$ & $(0.004)$ \\
\hline \multirow[t]{2}{*}{ Union density } & $-0.003^{* * *}$ & $-0.003^{* *}$ & $-0.003^{* * *}$ & -0.002 & -0.004 \\
\hline & $(0.001)$ & $(0.001)$ & $(0.001)$ & $(0.001)$ & $(0.005)$ \\
\hline \multirow[t]{2}{*}{ Globalization } & 0.001 & 0.001 & -0.001 & -0.000 & -0.005 \\
\hline & $(0.003)$ & $(0.003)$ & $(0.002)$ & $(0.002)$ & $(0.006)$ \\
\hline $\mathrm{N}$ & 414 & 405 & 344 & 337 & 353 \\
\hline \multicolumn{6}{|l|}{ First-stage results } \\
\hline \multirow[t]{2}{*}{ Coefficient IV } & $0.012^{* * *}$ & $0.012^{* * *}$ & $0.056^{* * *}$ & $0.056^{* * *}$ & -0.136 \\
\hline & $(0.002)$ & $(0.002)$ & $(0.012)$ & $(0.011)$ & $(0.179)$ \\
\hline F-Statistic & 26.24 & 29.13 & 20.70 & 26.15 & 0.57 \\
\hline
\end{tabular}

[1] Dependent Var: UTIP estimate [2] 2SLS IV Estimations [3] IVs are extrapoltaed values of core expl. variables [4] First-stage results display coefficients in first-stage regressions of instrumented var on IV [5] Country and year fixed effects in all specifications [6] Standard errors cluster adjusted for countries [6] $*<0.10, * *<0.05, * * *<0.01$ 


\section{References}

Abadie, A., A. Diamond, and J. Hainmueller (2010). Synthetic control methods for comparative case studies: Estimating the effect of california's tobacco control program. Journal of the American Statistical Association 105(49), 493 - 505.

Abadie, A. and J. Gardeazabal (2003). The economic costs of conflict: A case study of the basque country. The American Economic Review 93(1), 113-132.

Acemoglu, D. and J. A. Robinson (2002). The political economy of the kuznets curve. Review of Development Economics 6(2), 183-203.

Angrist, J. D. and J. S. Pischke (2009). A note on the bias in just identified IV with weak instruments. http://econ.lse.ac.uk/staff/spischke/mhe/ josh/solon_justid_April14.pdf (accessed September 2011).

Arellano, M. and S. Bond (1991). Some tests of specification for panel data: Monte carlo evidence and an application to employment equations. Review of Economic Studies 58(2), 277-297.

Arellano, M. and O. Bover (1995). Another look at the instrumental variable estimation of error-components models. Journal of Econometrics 68(1), 29 51.

Atkinson, A. B. and A. Brandolini (2001). Promise and pitfalls in the use of "secondary" data-sets: Income inequality in oecd countries as a case study. Journal of Economic Literature 39(3), pp. 771-799.

Besley, T. and A. Case (2000). Unnatural experiments? Estimating the incidence of endogenous policies. The Economic Journal 110(467), 672-694.

Blundell, R. and S. Bond (1998). Initial conditions and moment restrictions in dynamic panel data models. Journal of Econometrics 87(1), 115 - 143.

Calderon, C. and A. Chong (2009). Labor market institutions and income inequality: an empirical exploration. Public Choice 138, 65-81.

Checchi, D. and C. Garcia-Penalosa (2008). Labour market institutions and income inequality. Economic Policy 23(56), 601-649.

Checchi, D. and C. Garcia-Penalosa (2010). Labour market institutions and the personal distribution of income in the oecd. Economica 77(307), 413-450.

Chong, A. and M. Gradstein (2007). Inequality and institutions. Review of Economics and Statistics 89(3), 454-465.

Cooper, D. H., B. F. Lutz, and M. G. Palumbo (2011). Quantifying the role of federal and state taxes in mitigating income inequality. Federal Reserve Bank 
of Boston Public Policy Discussion Paper 11-7.

Deininger, K. W. and L. Squire (1996). A new data set measuring income inequality. World Bank Economic Review 10(3), 565-91.

Dreher, A. (2006). Does globalization affect growth? evidence from a new index of globalization. Applied Economics 38(10), 1091-1110.

Duncan, D. and K. Sabirianova-Peter (2008). Tax progressivity and income inequality. Andrew Young School of Policy Studies Research Paper Series 08-26.

Frey, B. S. and A. Stutzer (2002). What can economists learn from happiness research? Journal of Economic Literature 40(2), pp. 402-435.

Fuest, C., J. Niehues, and A. Peichl (2010). The redistributive effects of tax benefit systems in the enlarged eu. Public Finance Review 38(4), 473-500.

Galbraith, J. (2009). Inequality, unemployment and growth: New measures for old controversies. Journal of Economic Inequality 7, 189-206.

Galbraith, J. K. and H. Kum (2005). Estimating the inequality of household incomes: A statistical approach to the creation of a dense and consistent global data set. Review of Income and Wealth 51(1), 115-143.

Garfinkel, I., L. Rainwater, and T. M. Smeeding (2006). A re-examination of welfare states and inequality in rich nations: How in-kind transfers and indirect taxes change the story. Journal of Policy Analysis and Management 25(4), 897-919.

Hayes, K. J., D. J. Slottje, and S. Porter-Hudak (1991). Us federal redistributive income policies. Applied Economics 23(7), 1193-1200.

Heston, A., R. Summers, and B. Aten (2009). Penn world table version 6.3. Center for International Comparisons of Production, Income and Prices at the University of Pennsylvania, http://pwt. econ. upenn. edu/ (accessed Jan. 2012).

Kuznets, S. (1955). Economic growth and income inequality. The American Economic Review 45(1), pp. 1-28.

LIS (2012). Luxembourg income study (LIS) database. http://www . lisdatacenter .org/our-data/lis-database/ (accessed Jan. 2012).

Meltzer, A. H. and S. F. Richard (1981). A rational theory of the size of government. Journal of Political Economy 89(5), 914-927.

Niehues, J. (2010). Social spending generosity and income inequality: A dynamic panel approach. IZA Discussion Paper No 5178. 
OECD (2011). Divided we stand. why inequality keeps rising. http: //www. oecd-ilibrary.org/social-issues-migration-health/ the-causes-of-growing-inequalities-in-oecd-countries_ 9789264119536-en (accessed March 2012).

OECD (2012a). Employment database. http://www . oecd.org/document/34/0, 3343, en_2649_33927_40917154_1_1_1_1,00.html (accessed Jan. 2012).

OECD (2012b). Main economic indicators. http://www.oecd.org/std/mei (accessed Jan. 2012).

OECD (2012c). Population and labor force statistics. http://www.oecd.org/ std/labour (accessed Jan. 2012).

OECD (2012d). Social expenditure database. http://www.oecd.org/els/ social/expenditure (accessed Jan. 2012).

Poterba, J. M. (2007). Income inequality and income taxation. Journal of Policy Modeling 29(4), 623-633.

Roed, K. and S. Strom (2002). Progressive taxes and the labour market: Is the trade-off between equality and efficiency inevitable? Journal of Economic Surveys 16(1), 77-110.

Roine, J., J. Vlachos, and D. Waldenstroem (2009). The long-run determinants of inequality: What can we learn from top income data? Journal of Public Economics 93(7-8), $974-988$.

Roodman, D. (2009). How to do xtabond2: An introduction to difference and system GMM in stata. Stata Journal 9(1), 86-136.

Sabirianova-Peter, K., P. Buttrick, and D. Duncan (2010). Global reform of personal income taxation, 1981-2005: Evidence from 189 countries. National Tax Journal 63(3), $447-478$.

Samanni, M., J. Teorell, S. Kumlin, and B. Rothstein (2010). The QoG social policy dataset, version 11nov10. University of Gothenburg: The Quality of Government Institute, http://www.qog.pol.gu.se (accessed Jan. 2012).

Schwabish, J., T. M. Smeeding, and L. Osberg (2006). Income distribution and social expenditure: A cross-national perspective. In D. Papadimitriou (Ed.), The Distributional Effects of Government Spending and Taxation, pp. 247 288. Northampton, USA: Edward Elgar Publishing.

Sinn, H.-W. (1995). A theory of the welfare state. The Scandinavian Journal of Economics 97(4), 495-526. 
United Nations (2012). Statistics divison. national accounts main aggregates database. http://unstats.un.org/unsd/snaama/Introduction.asp (accessed Jan. 2012).

UNU-WIDER (2008). World income inequality database. User guide and data sources. http://62.237.131.23/wiid/WIID2c.pdf (accessed Jan. 2012).

Worldbank (2012). The world development indicators. resource document. http: //databank.worldbank.org/ (accessed Jan. 2012). 